\title{
Effects of net cages on the vertical distribution of zooplankton in a semi-arid reservoir, northeastern Brazil
}

\author{
Interferência de tanques-rede na distribuição vertical do
}

zooplâncton num açude do semi-árido, nordeste do Brasil

\author{
Glécia Trinta de Paula Freitas ${ }^{1}$, Maria Cristina Crispim ${ }^{1}$ and \\ Hênio do Nascimento de Melo Júnior ${ }^{2}$
}

\author{
${ }^{1}$ Laboratório de Ecologia Aquática - LABEA, Departamento de Sistemática e Ecologia, \\ Centro de Ciências Exatas e da Natureza - CCEN, Universidade Federal da Paraíba - UFPB, \\ Campus I, Cidade Universitária, CP 5122, CEP 58051-900, João Pessoa, PB, Brazil \\ e-mail: glecia30@yahoo.com.br; ccrispim@hotmail.com \\ ${ }^{2}$ Laboratório de Limnologia e Aqüicultura, Departamento de Ciências Biológicas, \\ Universidade Regional do Cariri - URCA, Rua Cel. Antônio Luis, 1161, Pimenta, \\ CEP 63105-00, Crato, CE, Brazil \\ e-mail: heniolimnologia@yahoo.com.br
}

\begin{abstract}
Aim: Carneiro reservoir is an aquatic environment used for net cage aquaculture activities, located in the semi-arid region of northeastern Brazil. Vertical distribution was evaluated in order to determine the effects of organic enrichment induced by aquaculture on zooplankton movements. Methods: three replicate samples were collected during midday and midnight at each of three depths along the water column (i.e. surface: $0 \mathrm{~m}$; middle: $2 \mathrm{~m}$ and bottom: $4 \mathrm{~m}$ ) at two sites (near and far from the net cages). Samples were collected using a $3 \mathrm{~L}$ volume capacity Van Dorn bottle. The collected individuals were preserved in a $4 \%$ formaldehyde solution saturated with sugar and, later, identified and counted on a Sedgwick-Rafter chamber under a microscope, considering a minimum of 100 individuals per subsample. Results: higher species richness and density were observed at the $\mathrm{N}$ station (nearby the net cages) compared to the $\mathrm{F}$ station (distant from the net cages). With few exceptions, Rotifer species did not exhibit typical vertical migration patterns, concentrating at bottom depths during daytime and at intermediate depths during nighttime. Brachionus dolabratus and Hexarthra mira were the only species to show reverse vertical migration at the $\mathrm{N}$ station, in opposition to patterns of the cyclopoid copepod Termocyclops crassus. Furthermore, vertical migration patterns were not clear for Cladocera and Copepoda species nearby the net cages, but were rather clear at the F station. Conclusions: the presence of fish net cages increased zooplankton species richness (mostly rotifers) and density. Vertical movements were more pronounced at sites distant from net cages, suggesting that the increased food availability reduced the need for the typical vertical movements during daytime at sites nearby the net cages.
\end{abstract}

Keywords: vertical distribution, fish net cages, semi arid region, zooplankton.

Resumo: Objetivo: $\mathrm{O}$ açude do Carneiro é um ambiente aquático utilizado para atividades de aquicultura em tanques-rede, localizado na região semi-árida do nordeste do Brasil. A distribuição vertical foi avaliada com a finalidade de determinar os efeitos do enriquecimento orgânico induzido pela aquicultura nos movimentos do zooplâncton. Métodos: três réplicas amostrais foram coletadas à meia noite (0:00 horas) e ao meio dia (12:00 horas ) em cada uma de três profundidades da coluna d'água (i.e. superfície: $0 \mathrm{~m}$; meio: $2 \mathrm{~m}$ e fundo: $4 \mathrm{~m}$ ) em duas áreas (próximo e distante dos tanques-rede). As amostras foram coletadas utilizando uma garrafa de Van Dorn com 3 L de capacidade volumétrica. Os indivíduos coletados foram preservados em uma solução de formol a $4 \%$ saturada com açúcar e, posteriormente, identificados e quantificados com uma câmara de contagem Sedgwick-Rafter sob microscópio, considerando um mínimo de 100 indivíduos por subamostra. Resultados: a riqueza de espécies e a densidade foram maiores na estação $\mathrm{N}$ (próxima aos tanques-rede) quando comparadas com a estação $\mathrm{F}$ (distante dos tanques-rede). Com poucas exceções, espécies de Rotifera não exibiram padrôes típicos de migração vertical, concentrando-se nas camadas mais profundas durante o dia e nas camadas intermediárias durante a noite. Brachionus dolabratus e Hexarthra mira foram as únicas espécies que mostraram padrôes de migração vertical inversos na estação 
N, em oposição aos padrōes do copépodo ciclopóide Termocyclops crassus. Além disso, padrôes de migraçáo vertical não foram claros para as espécies de Cladocera e Copepoda próximos aos tanques-rede, mas foram evidentes na estação F. Conclusóes: a presença de tanques-rede para peixes aumentou a riqueza de espécies (a maioria rotíferos) e a densidade de zooplâncton. Movimentos verticais foram mais pronunciados nos locais distantes dos tanques-rede, sugerindo que o aumento da disponibilidade de alimento reduziu a necessidade dos movimentos verticais típicos durante o dia, nos locais próximos aos tanques-rede.

Palavras-chave: distribuição vertical, tanques-rede de peixes, região semi-árida, zooplâncton.

\section{Introduction}

Daily cycles, including diel vertical migrations, are typical of zooplankton organisms. Several environmental factors, namely, water temperature, dissolved oxygen and water transparency may potentially induce and influence patterns of zooplankton vertical distribution (Wissel and Ramacharan, 2003). Nevertheless, predator avoidance is deemed to be a major hypothesis explaining the adaptive advantages of this periodic vertical movement (Haney, 1988; Pearre Junior, 2003; Wissel and Ramacharan, 2003). Given the metabolic costs of this behavior, location of zooplankton within the water column during daytime appears to be regulated by the level of predator risk (Bollens and Frost, 1989; Van Gool and Ringelberg, 1998a).

Typically, zooplankton individuals vulnerable to planktivory stay at deeper waters during daytime, where visual fish predators are less likely to be successful at their capture. During nighttime, however, these individuals migrate to surface waters where food quality is higher (Iwasa, 1982; Stirling et al., 1990; Ringelberg, 1991a, b).

Vertical migration is a size-dependent behavior, given that the small size of several zooplankton species constrains visual detection by predators. These species, therefore, do not exhibit periodic vertical migrations, permanently staying at nutrient-rich, surface waters, where food intake is, theoretically, more efficient than that of migrating species (Guisande et al., 1991).

Invertebrate predators, such as cyclopoid copepods may also potentially prey on small zooplankton, mostly rotifers (Williamson, 1983; Plaßmann et al., 1997), thus influencing the structure and dynamics of the overall plankton community (Haney, 1988; Karabin, 1978; Matsumura-Tundisi et al., 1990). In this way, these non-visual predators also play an important role regulating zooplankton migration processes (Haney, 1988).
Aside from predation, food availability is also an important factor influencing the vertical distribution of zooplankton. Flik and Ringelberg (1993) observed that individuals remain at surface depths with high predation pressure when food availability is very low. This comes about when the costs of periodically avoiding a depth of high predation-risk outweigh the benefits, in a so-called 'better dead than unfed' strategy (Liu et al., 2003).

Given the abovementioned, the present study aimed to evaluate the influence of net cages on the vertical distribution of zooplankton individuals at Carneiro reservoir (semi-arid northeastern region of Brazil) between two sampling stations located near and far from cultivation sites. Specifically, the following hypothesis was tested: the presence of net cages negatively affects the vertical distribution of zooplankton individuals.

\section{Methodology}

Carneiro reservoir is located at Jericó city, semiarid region of Paraíba state, northeastern Brazil. The reservoir has a maximum volume capacity of 31,000,000 m³ (Açude Carneiro, 2010) (Figure 1) where fish culture in open net cages is amongst the most common activities. The reservoir is located at an altitude of $289 \mathrm{~m}$ (Google Earth). Published data on limnological conditions at this site are unknown.

Water transparency was determined via Secchi disk depth.

Zooplankton samples were collected at 12:00 PM and 12:00 AM using a $3 \mathrm{~L}$ volume capacity Van Dorn bottle (totaling $12 \mathrm{~L}$ of collected water) at depths of $0 \mathrm{~m}$ (surface), $2 \mathrm{~m}$ (intermediate depth) and $4 \mathrm{~m}$ (bottom). The collected individuals were preserved in a $4 \%$ formaldehyde solution saturated with sugar.

Zooplankton individuals were collected at two stations. The $\mathrm{N}$ station was a nearby site, located $0.5 \mathrm{~m}$ from the net cages at coordinates ( $6^{\circ} 31^{\prime} 26^{\prime \prime} \mathrm{S}$ and $\left.37^{\circ} 50^{\prime} 55^{\prime \prime} \mathrm{W}\right)$, whereas the $\mathrm{F}$ station was a far site located approximately $100 \mathrm{~m}$ from net cages 
at coordinates $6^{\circ} 31^{\prime} 21^{\prime \prime} \mathrm{S}$ and $37^{\circ} 50^{\prime} 57^{\prime \prime} \mathrm{W}$. Individuals at the former station are most likely to be influenced by fish culture activities, the opposite being true for the latter station. Further, to evaluate day-night shifts and differences in vertical distribution patterns between stations samples were conducted at noon and at midnight.

Three replicates were collected at the surface, intermediate and bottom depths of sampling stations $\mathrm{N}$ and $\mathrm{F}$. The average densities of the three replicates, expressed as ind. $\mathrm{L}^{-1}$, were used as the representative of each depth.

The collected individuals were identified and counted on a Sedgwick-Rafter chamber under a microscope. A minimum of 100 individuals of each sample were counted. Taxonomic identification followed Ruttner-Kolisko (1974) and Koste (1978) for rotifers, El Moor-Loureiro (1997) for cladocerans, and Reid (1985) and Wright (1936) for copepods.

To evaluate differences among depths (i.e. surface, intermediate and bottom), a one-way ANOVA was conducted. In the case of significance, Tukey's test was used to assess multiple comparisons of means. Further, non-parametric Kruskal-Wallis rank test was conducted whenever ANOVA assumptions were violated. Statistical analyses were conducted on Statistica software for Microsoft Windows (Statsoft, 1998).

\section{Results}

Water transparency differed between stations due to lower values observed at station $\mathrm{N}$ compared to station F. Average values of Secchi disk depth were $0.80 \mathrm{~m}$ in $\mathrm{N}$ station $( \pm 0.00 \mathrm{SD})$ and $0.74 \mathrm{~m}$ $(0.05)$ in $\mathrm{F}$ station.

A summary of the collected zooplankton species is shown in Table 1. In general, zooplankton composition was seemingly similar at the two stations. Nevertheless, station N (16 species) showed higher species richness than station F (12 species).

The largest crustacean species recorded during the study were the calanoid copepod Notodiaptomus cearensis Wright, 1936, the cyclopoid copepod Thermocyclops crassus Fischer, 1853, and the cladoceran Ceriodaphnia cornuta Sars, 1885 (Table 1). Moreover, although Diaphanosoma spinulosum Herbst, 1975 was recorded at Carneiro reservoir (Table 1 ), its very low density and frequency constrained a comparative analysis.

ANOVA results revealed that $C$. cornuta was mostly abundant at the intermediate depth of station $\mathrm{N}$, during daytime. Further, $N$. cearensis and

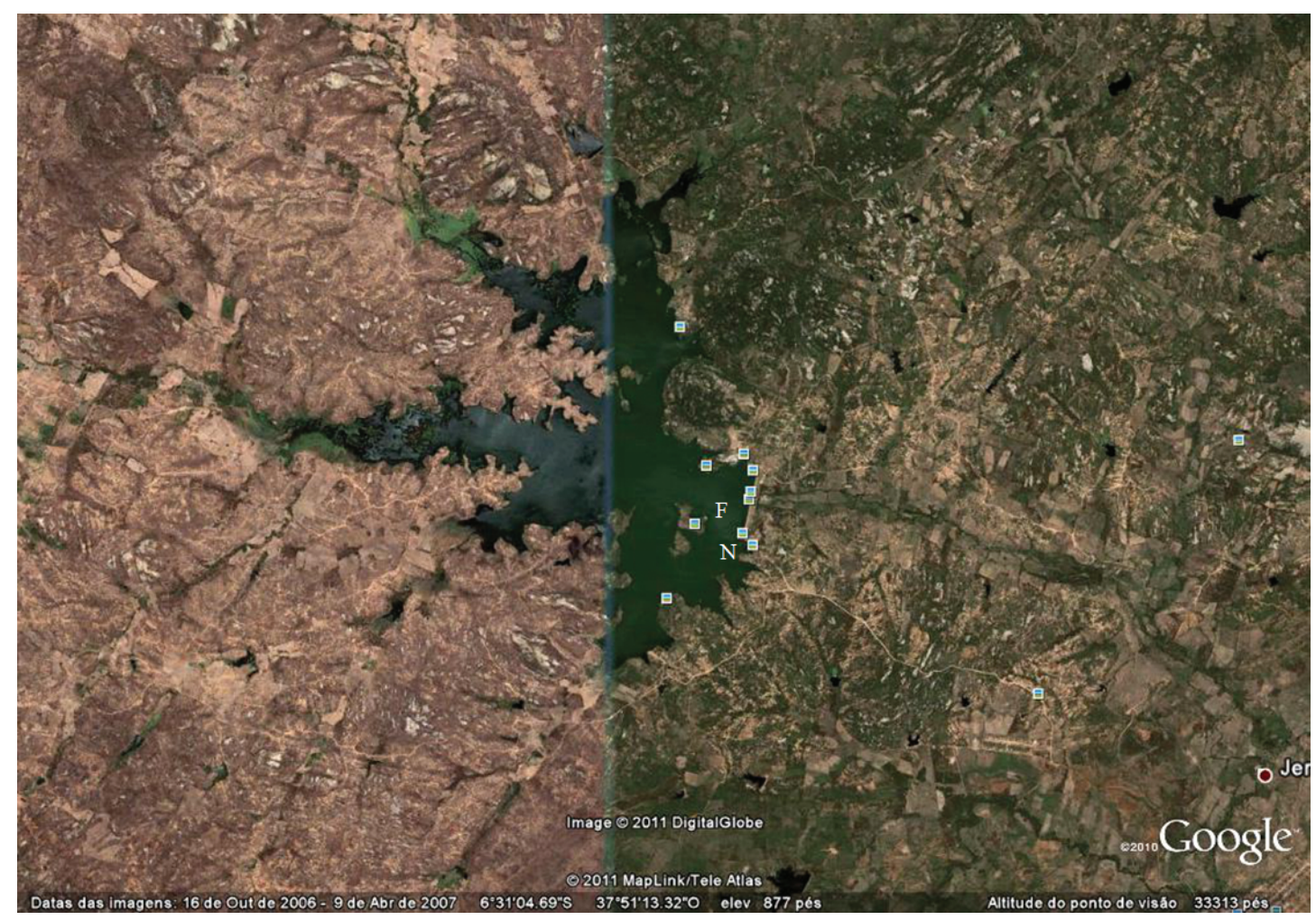

Figure 1. Location of Carneiro reservoir, Jericó, Paraíba, Brazil. 

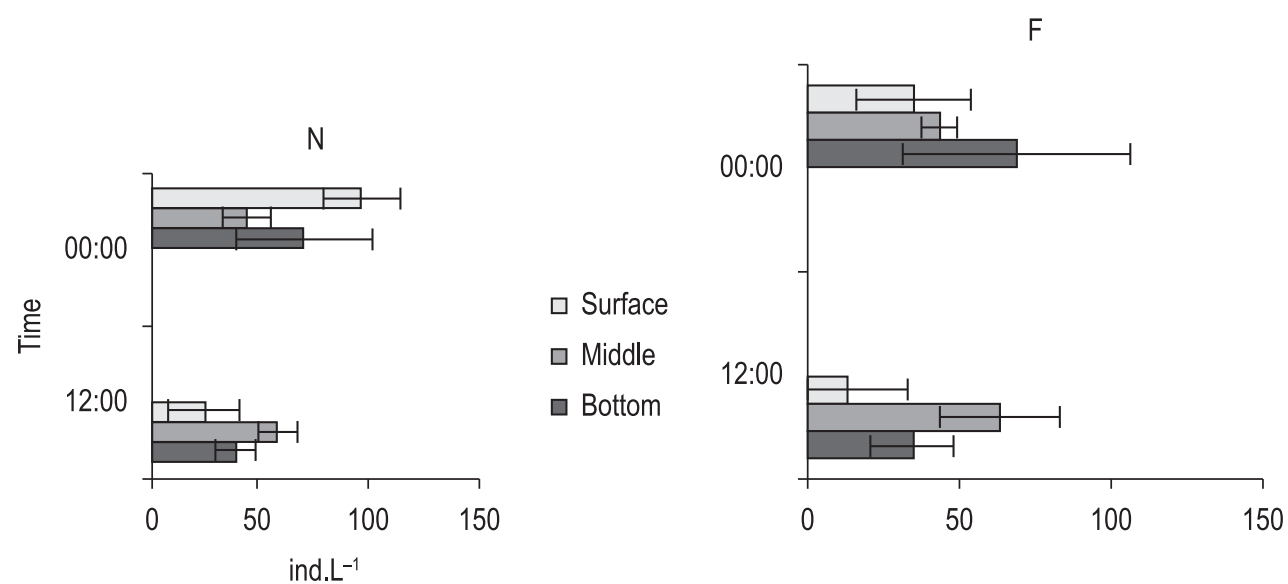

Figure 2. Density (ind. $\mathrm{L}^{-1}$ ) of Ceriodaphnia cornuta at the $\mathrm{N}$ and $\mathrm{F}$ stations, during night (12:00 PM) and day (12:00 AM) at three depths (surface, intermediate, bottom). Lines at each bar represent standard deviation measures.
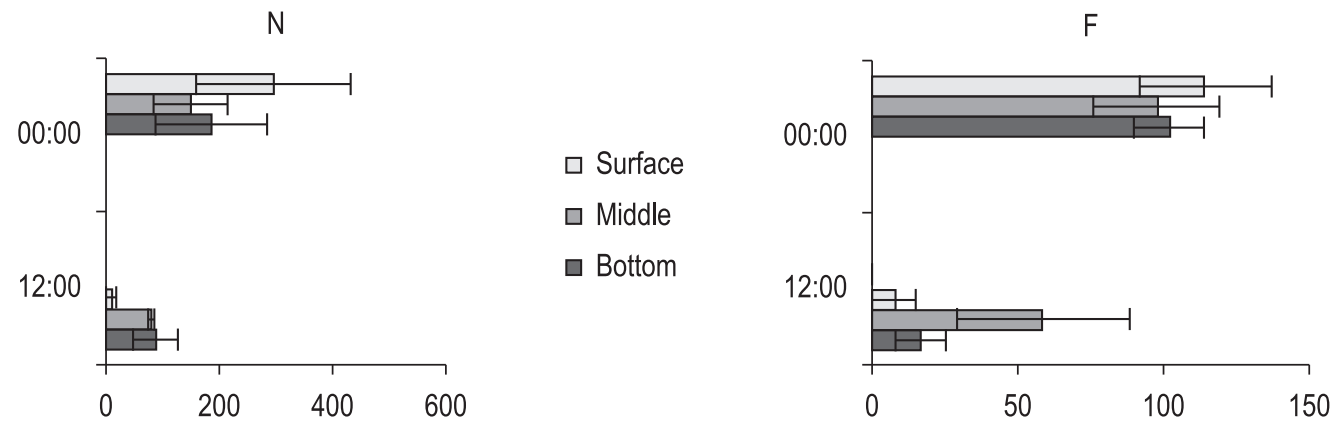

Figure 3. Density (ind. $\left.\mathrm{L}^{-1}\right)$ of Notodiaptomus cearensis at the $\mathrm{N}$ and F stations, during night (12:00 PM) and day (12:00 AM) at three depths (surface, intermediate, bottom). Lines at each bar represent standard deviation measures.

$\mathrm{N}$

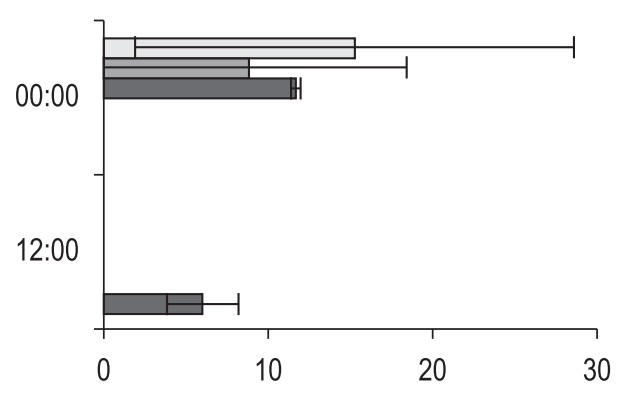

F

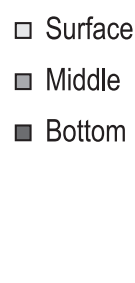

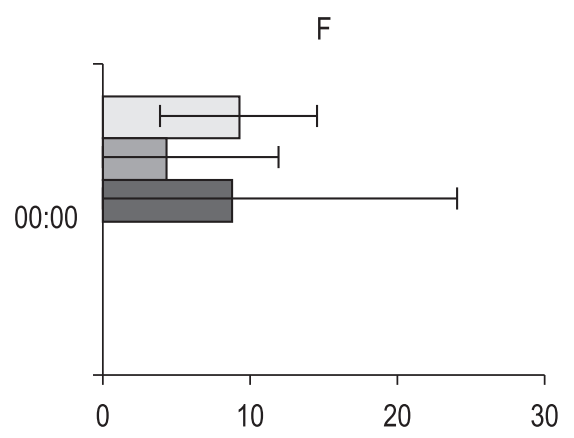

Figure 4. Density (ind. $\mathrm{L}^{-1}$ ) of cyclopoid copepod Termocyclops crassus at the N and F stations, during night (12:00 PM) and day (12:00 AM) at three depths (surface, intermediate, bottom). Lines at each bar represent standard deviation measures.

T. crassus were also more abundant at deeper waters (depths of 2 and $4 \mathrm{~m}$, respectively) during daytime (Table 1; Figures 2-4).

At the F station, during daytime, the cladoceran C. cornuta was more abundant at the intermediate depth, whereas during nighttime they were significantly more abundant at the bottom (F station) and surface ( $\mathrm{N}$ station) (Figure 1 )
(Table 2). Water transparency increased with distance from net cages and C. cornuta individuals avoided surface waters, even during nighttime, at these sites. Conversely, high turbidity nearby net cages prompted individuals of this species to feed on the surface depth, which has optimal feeding conditions. Therefore, at the $\mathrm{N}$ station, due to higher turbidity, this species showed 
periodic migration to the surface, whereas at the F station, which is not influenced by aquaculture activities, vertical migration was precluded due to the existence of clear waters even at night. A higher number of Calanoid copepods was collected during night. These individuals concentrated on the bottom during daytime and showed a somewhat homogenous distribution along the water column during nighttime. Cyclopoid copepods were not recorded at the $\mathrm{F}$ station during daytime. At the $\mathrm{N}$ station, individuals of this species were recorded solely on the bottom at night, whereas during daytime individuals were evenly dispersed throughout the water column (Figure 4).

Rotifer species such as Brachionus havanaensis Rousselet, 1911, B. calyciflorus Pallas, 1776 and Keratella tropica Apstein, 1907, along with cyclopoid copepodites did not reveal migration patterns at neither station. On the other hand, Brachionus dolabratus Harring, 1914 individuals were mostly abundant at the surface and intermediate depths of the reservoir during daytime at both stations. During nighttime, this species was recorded solely at the surface (Figure 5)
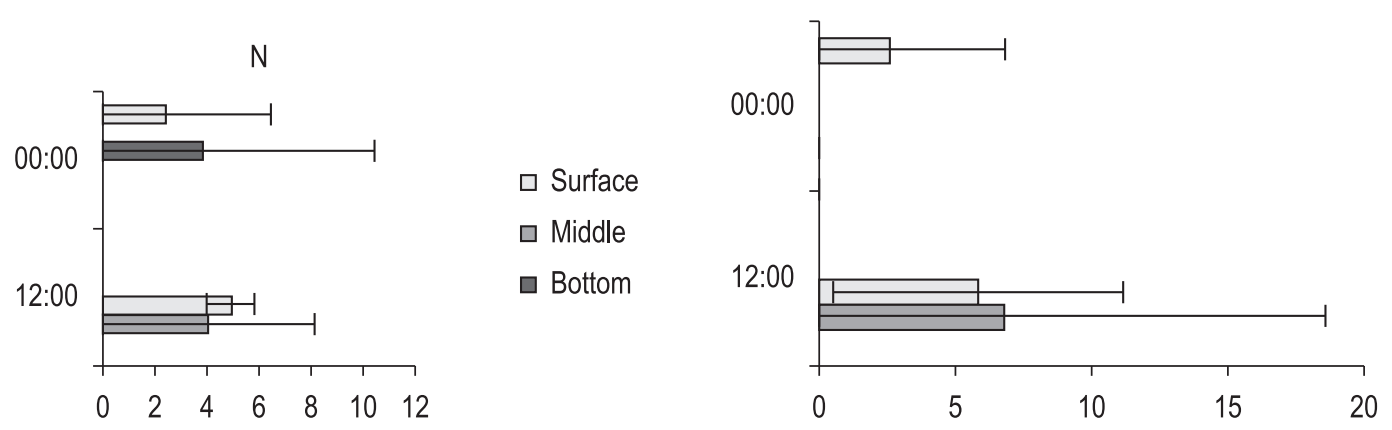

Figure 5. Density (ind. $\mathrm{L}^{-1}$ ) of Brachionus dolabratus at the $\mathrm{N}$ and F stations, during night (12:00 PM) and day (12:00 AM) at three depths (surface, intermediate, bottom). Lines at each bar represent standard deviation measures.

Table 1. Zooplanktonic species recorded at the two evaluated sampling stations ( $\mathrm{N}$ and $\mathrm{F}$ ) at Carneiro reservoir.

\begin{tabular}{lll}
\hline \multicolumn{1}{c}{ Rotifera } & \multicolumn{2}{c}{ Stations N F } \\
\hline Brachionus calyciflorus & $\mathrm{x}$ & $\mathrm{x}$ \\
B. dolabratus & $\mathrm{x}$ & $\mathrm{x}$ \\
B. havanaensis & $\mathrm{x}$ & $\mathrm{x}$ \\
Euchlanis dilatata & $\mathrm{x}$ & \\
Filinia longiseta & $\mathrm{x}$ & $\mathrm{x}$ \\
F. opoliensis & $\mathrm{x}$ & $\mathrm{x}$ \\
Keratella tropica & $\mathrm{x}$ & $\mathrm{x}$ \\
K. quadrata & $\mathrm{x}$ & \\
Keratella cochlearis & $\mathrm{x}$ & $\mathrm{x}$ \\
Lecane luna & $\mathrm{x}$ & \\
Hexarthra mira & $\mathrm{x}$ & $\mathrm{x}$ \\
$\quad$ & & \\
$\quad$ Cladocera & & \\
Alona poppei & $\mathrm{x}$ & \\
Ceriodaphnia cornuta & $\mathrm{x}$ & $\mathrm{x}$ \\
Diaphanosoma spinulosum & $\mathrm{x}$ & $\mathrm{x}$ \\
\multicolumn{1}{c}{ Copepoda Calanoida } & & \\
Notodiaptomus cearensis & $\mathrm{x}$ & $\mathrm{x}$ \\
$\quad$ Copepoda Ciclopoida & & \\
Thermocyclops crassus & $\mathrm{x}$ & \\
\hline
\end{tabular}

Table 2. Results of ANOVA and Tukey's test on the differences in zooplanktonic densities among Surface $(S)$, Intermediate (M) and Bottom (B) depths at 12:00 PM and 12:00 AM, at the $\mathrm{N}$ and F stations. Note that only the variables which showed significant differences (at the $5 \%$ level) are shown.

\begin{tabular}{lccc}
\hline & \multicolumn{3}{c}{ ANOVA-12:00 PM } \\
\cline { 2 - 4 } & $\mathbf{F ~ ( 2 . 6 )}$ & $\boldsymbol{p}$ value & Tukey \\
\hline $\mathbf{N}$ & & & \\
Nauplii & 6.3 & 0.04 & $\mathrm{~S}<\mathrm{B}$ \\
Filinia opoliensis & $\mathbf{1 0 . 1 5}$ & $\mathbf{0 . 0 1}$ & $\mathbf{S}<\mathrm{M}=\mathbf{B}$
\end{tabular}

$\mathbf{F}$

Filinia opoliensis

\begin{tabular}{rrr}
5.58 & 0.04 & $S<M>B$ \\
\multicolumn{3}{c}{ ANOVA-12:00 AM } \\
F (2.6) & p value & Tukey \\
& & \\
6.08 & 0.036 & $S<M=B$ \\
21.33 & $\mathbf{0 . 0 0 1}$ & $S<M=B$ \\
21.54 & 0.002 & $S<M=B$
\end{tabular}


of the F station, and at the surface and bottom of the $\mathrm{N}$ station. This suggests that $B$. dolabratus avoids invertebrate predators such as the copepod T. crassus during daytime at both stations. During daytime, this cyclopoid copepod was restricted to the bottom at the F station and was not recorded at the $\mathrm{N}$ station. A similar result was obtained by Crispim (1998), which observed an inverse pattern of vertical distribution between some rotifer species and cyclopoid copepods. Furthermore, this pattern may be related to the lack of vertical movements, as commonly observed for rotifers. Due to the higher availability of food at the $\mathrm{N}$ station, migratory behaviors seem not to be required at this site. On the other hand, at the F station, the benefits of migrating to a depth of higher organic matter and phytoplankton concentrations outweigh the energy costs involved in their dislocation.

At the F station, Hexarthra mira Hudson, 1871 did not exhibit vertical migration patterns. Nevertheless, at the $\mathrm{N}$ station, individuals of this species were recorded exclusively at the surface during daytime and exclusively at the bottom during nighttime (Figure 6), suggesting a typical vertical reverse migration. As previously described, the higher food availability at the $\mathrm{N}$ station enabled this species to stay at the bottom in order to avoid copepods. In the present study, this species, along with $B$. dolabratus, were the only rotifers showing migratory behaviors in opposition to the pattern observed by T. crassus (Figure 4). The other rotifers did not exhibit migratory behaviors.

Within nauplii, individuals were most abundant at deeper waters (2 and $4 \mathrm{~m}$ depths) during nighttime, particularly at the $\mathrm{N}$ station (Figure 7 ). During daytime, however, significant vertical differences were not observed for these individuals. A similar pattern of vertical distribution was recorded for Filinia opoliensis Zacharias, 1898, which was mostly abundant at deeper waters (2 to $4 \mathrm{~m}$ depths) during nighttime at both stations (Figure 8) and concentrated at intermediate waters (i.e. $2 \mathrm{~m}$ depth) during daytime.

\section{Discussion}

The higher number of zooplankton species recorded at the $\mathrm{N}$ station is probably an effect of net cages providing additional surface areas for biofilm development. Phytoplankton is an important source of food for several herbivores, supporting niche diversification and, thus, increasing the complexity of trophic webs. In addition, the $\mathrm{N}$ station is subject to higher nutrient concentrations, as a consequence of aquaculture activities, therefore increasing food supply at this site when compared to the F station. In fact, this increase in nutrient concentration reflected on observed lower water transparency values at the former site.

Larger zooplankton species tended to concentrate at deeper waters during daytime, where predation risk by visual predators was minimized. By performing a periodic vertical movement, these individuals avoid the surface layers during periods of high predation susceptibility (Pearre Junior, 2003; Wissel and Ramacharan, 2003). Visual planktivores depend on optimal light conditions to increase prey capture efficiency, selectively picking remaining zooplankton individuals at the surface depths during daytime (Haney, 1988). Thus, diel vertical migration is an important predator-avoidance strategy employed by zooplankton individuals (Zaret, 1980; Stirling et al., 1990; Pearre Junior, 2003; Wissel and Ramacharan, 2003) regardless of the energy costs involved (Guisande et al., 1991). Given the high vulnerability of large-bodied zooplankton individuals to visual predators, migratory behaviors, concentrating individuals at deeper waters during daytime, is vital for these organisms. In the present study, selection of deeper waters during daytime was observed, particularly, for copepods.

Vertical migration is also dependent upon differences in temperature and food concentration between the surface and the bottom (Dawidovicz and Loose, 1992). Not only visual detection of zooplankton individuals by planktivores decreases with depth, but also temperature and, frequently, food availability (Van Gool and Ringelberg, 1998b).

$S$ mall zooplankton species (i.e. Brachionus havanaensis, B. calyciflorus, $K$. tropica and cyclopoids copepodites) did not exhibit migratory behavior at any of the evaluated stations due to their low visibility and, hence, lower predation risk. In fact, compared to large crustaceans and insect larvae, rotifers make up an insignificant percentage of the diet of most vertebrate predators. Given the low predation risk by planktivorous fishes, these small zooplankton individuals remain at privileged surface waters, reducing the energetic costs involved in vertical dislocations and having permanent access to high-quality food (Guisande et al., 1991). On the other hand, the rotifer $B$. dolabratus, unusually, showed a typical vertical migration pattern at the $\mathrm{N}$ station. Specifically, higher abundances were observed at deeper and surface waters at 12:00 PM and 12:00 AM, respectively. At the F station, 
N

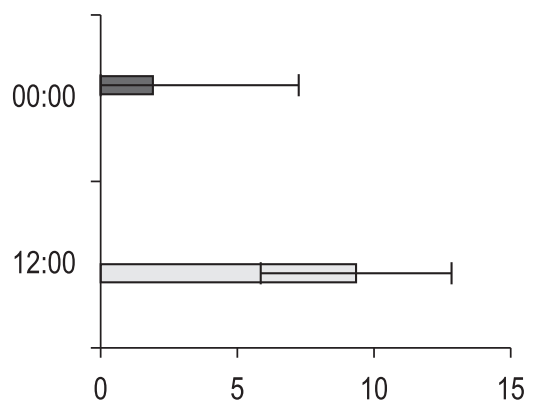

$\mathrm{F}$

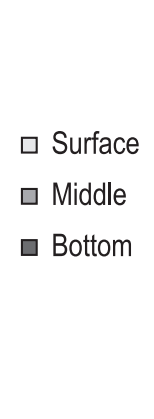

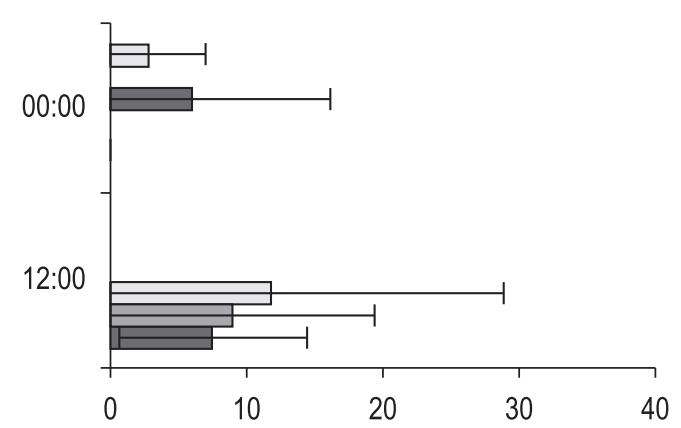

Figure 6. Density (ind. $\mathrm{L}^{-1}$ ) of Hexarthra mira at the $\mathrm{N}$ and F stations, during night (12:00 PM) and day (12:00 AM) at three depths (surface, intermediate, bottom). Lines at each bar represent standard deviation measures.

N

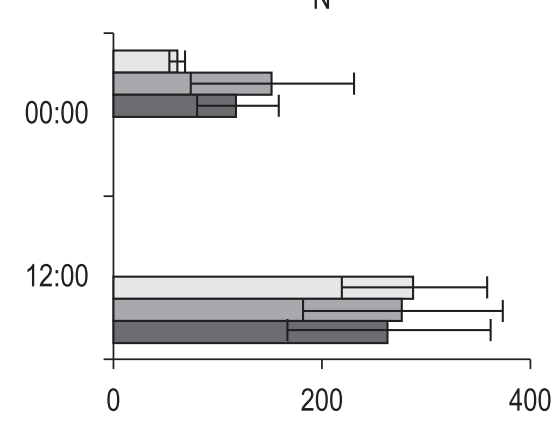

$\mathrm{F}$

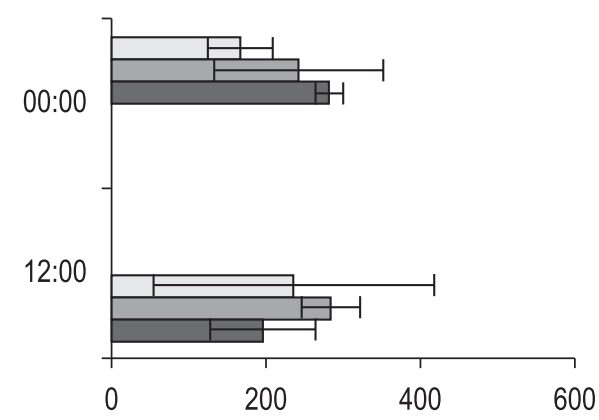

Figure 7. Density (ind. $\mathrm{L}^{-1}$ ) of nauplii at the $\mathrm{N}$ and $\mathrm{F}$ stations, during night (12:00 PM) and day (12:00 AM) at three depths (surface, intermediate, bottom). Lines at each bar represent standard deviation measures.
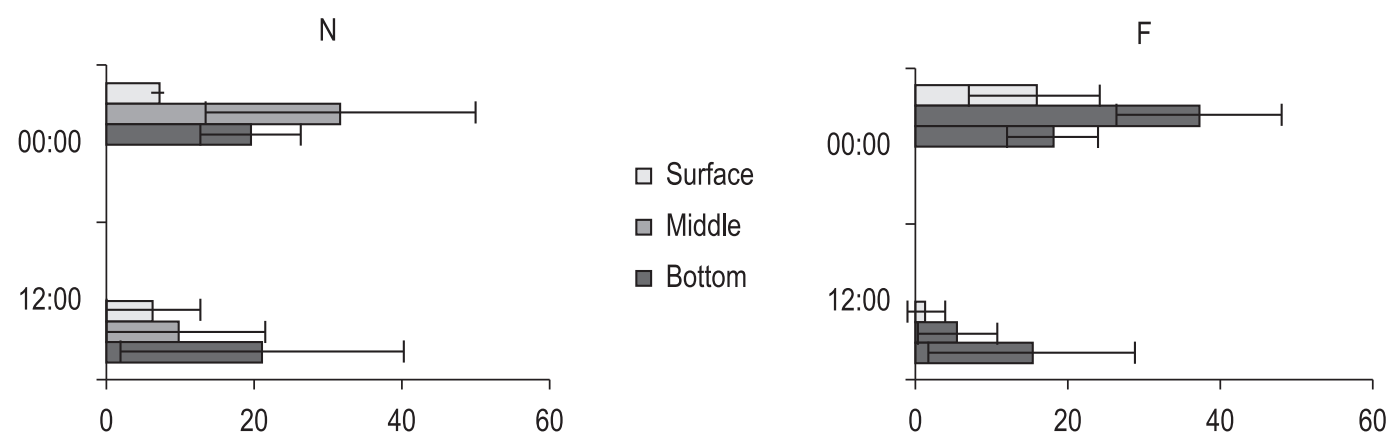

Figure 8. Density (ind. $\mathrm{L}^{-1}$ ) of Filinia opoliensis at the $\mathrm{N}$ and $\mathrm{F}$ stations, during night (12:00 PM) and day (12:00 AM) at three depths (surface, intermediate, bottom). Lines at each bar represent standard deviation measures.

individuals were evenly dispersed in the water column.

Rotifers, nevertheless, make up an important proportion of the diet of invertebrate predators. Williamson (1983) showed that percent cropping rates of the cyclopoid copepod Mesocyclops edax Forbes, 1890 towards rotifers were approximately twice as big as the observed for adult crustaceans. This significant predation pressure probably stimulated the 'reverse' migration pattern observed exclusively by the rotifer $H$. mira at the $\mathrm{N}$ station. Individuals of this species were mostly abundant at deeper waters during the night and at surface waters during the day, in an opposite pattern to that of the copepod $T$. crassus (the unique invertebrate predator recorded in the present study). Similarly, Polyarthra vulgaris and Pompholyx sulcata showed reverse migration patterns, in opposition to the movements of the cyclopoid copepod Acanthocyclops robustus at the Maranhão reservoir (Portugal) (Crispim, 1998). 
The rotifer F. opoliensis and nauplii were also more frequent at deeper waters (2 to $4 \mathrm{~m}$ ) during nighttime. However, during daytime they were evenly dispersed along the water column. Crispim (1998) also observed that nauplii and juvenile copepods may show reverse vertical migrations to avoid adult copepods.

Single factors, such as predation or food availability alone, are unlikely to be the sole cause of diel vertical migration by zooplankton individuals. At most natural ecosystems, migration patterns seem to be an effect of multiple factors (Gliwicz, 1986). However, in the present study, evidence suggests that higher food availability nearby the net cages inhibited vertical movements, such as the ones observed away from the net cages. A lack of migratory behavior suggests that individuals are under a somewhat low predation pressure, thus, saving energy that would be utilized on periodic vertical dislocations. At the $\mathrm{F}$ station, limited food availability compelled the individuals to rise to upper layers at night. Alternatively, migratory movements observed at the $\mathrm{N}$ station by some rotifers are possibly the result of higher density of cyclopoid copepods, species-specific predation pressure and/or increased competition, given that some herbivores did not exhibit vertical movements.

\section{References}

Açude Carneiro (Jericó). Wikimapia. Available from: $<$ http://wikimapia.org/6039458/pt/A\%C3\%A7udeCarneiro-Para\%C3\%ADba-Brasil>. Access in: 30 nov. 2010

BOLLENS, SM. and FROST, BW. 1989. Zooplanktivorous fish and variable diel vertication migration in the marine planktonic copepod Calanus pacificus. Limnology and Oceanography, vol. 34, p. 1072-1083. http://dx.doi.org/10.4319/ lo.1989.34.6.1072

CRISPIM, MC. 1998. Estudo do impacte do esvaziamento da Albufeira do Maranhão sobre a comunidade zooplanctônica - Principais relaçóes bióticas que afectam os cladóceros. Lisboa: Faculdade de Ciências da Universidade Lisboa. 183 p. [Tese de Doutorado em Ciências].

DAWIDOVICZ, P. and LOOSE, CJ. 1992. Metabolic costs during predator-induced diel vertical migration of Daphnia. Limnology and Oceanography, vol. 37, no. 8 , p. 1589-1595. http://dx.doi.org/10.4319/ lo.1992.37.8.1589

El MOOR-LOUREIRO, LMA. 1997. Manual de Identificação de Cladóceros Límnicos do Brasil. Brasília: Editora Universa. 155 p.
FLIK, BJG. and RINGELBERG, J. 1993. Influence of food availability on the initiation of diel vertical migration (DVM) in Lake Maarsseveen. Archiv für Hydrobiologie-Beiheft Ergebnisse der Limnologie, vol. 39, p. 57-65.

GLIWICZ, ZM. 1986. Predation and the evolutionof vertical migration in zooplankton. Nature, vol. 320, p. 746-748. http://dx.doi.org/10.1038/320746a0

GUISANDE, C., DUNCAN, A. and LAMPERT, W. 1991. Trade-offs in Daphnia vertical migration strategies. Oecologia, vol. 87, p. 357-359. http:// dx.doi.org/10.1007/BF00634591

HANEY, JF. 1988. Diel patterns of zooplankton behavior. Bulletin of Marine Science, vol. 43, no. 3, p. 583-603.

IWASA, I. 1982. Vertical migration of zooplankton: a game between predator and prey. The American Naturalist, vol. 120, no. 2, p. 171-180. http://dx.doi. org/10.1086/283980

KARABIN, A. 1978. The pressure of pelagic predators of the genus Mesocyclops (Copepoda, Crustacea) on small zooplankton. Ekologia Polska, vol. 26, p. 241257.

KOSTE, W. 1978. Rotatoria-Dieradertiere Mitteleuropas EinBestimmnngswerk, begründet von max voigt Überordnung Monogonta. Berlin: Gebrüder Borntraeger. $234 \mathrm{p}$.

LIU, S-H., SONG, S., HAN, B-P. 2003. Diel vertical migration of zooplankton following optimal food intake under predation. Journal of Plankton Research, vol. 25, no. 9, p. 1069-1077. http://dx.doi. org/10.1093/plankt/25.9.1069

MATSUMURA-TUNDISI, T., RIETZLER, AC., ESPINDOLA, ELG., TUNDISI, JG. and ROCHA, O. 1990. Predation on Ceriodaphnia cornuta and Brachionus calyciflorus by two Mesocyclops species coexisting in Barra Bonita reservoir (SP, Brazil). Hydrobiologia, vol. 198, p. 141-151. http://dx.doi. org/10.1007/BF00048631

PEARRE JUNIOR, S. 2003. Eat and run? The hunger/ satiation hypothesis in vertical migration: history, evidence and consequences. Biology Reviews, vol. 78, p. 1-79. PMid:12620061. http://dx.doi. org/10.1017/S146479310200595X

PLABMANN, T., MAIER, G. and STICH, HB. 1997. Predation impact of Cyclops vicinus on the rotifer community in Lake Constance in spring. Journal of Plankton Research, vol. 19, p. 1069-1079. http:// dx.doi.org/10.1093/plankt/19.8.1069

REID, JW. 1985. Chave de Identificação e lista de referências bibliográficas para as espécies continentais sulamericanas de vida livre da Ordem Cyclopoida (Crustacea:Copepoda). Boletim Zoológico da Universidade de São Paulo, vol. 9, p. 17-143.

RINGELBERG, J. 1991a. Enhancement of the phototactic reaction in Daphnia hyalina by a chemical 
mediatedby juvenile perch (Perca fluviatilis). Journal of Plankton Research, vol. 13, no. 1, p. 17-25. http:// dx.doi.org/10.1093/plankt/13.1.17

RINGELBERG, J. 1991b. A mechanism of a predatormediated induction of diel vertical migration in Daphnia hyalina. Journal of Plankton Research, vol. 13, no. 1, p. 83-89. http://dx.doi.org/10.1093/ plankt/13.1.83

RUTTNER-KOLISKO, A. 1974. Plankton rotifers, biology and taxonomy. Stuttgart: E. Schweizerbart'sche verlagsbuchhandlung. $146 \mathrm{p}$.

STATSOFT. 1998. Statistica for Windows (Computer Program Manual). Tulsa: Statsoft Inc.

STIRLING, DG., McQUEEN, DJ. and JOHANNES, MRS. 1990. Vertical migration in Daphnia galeata mendotae (Brooks): demographic responses to changes in planktivore abundance. Canadian Journal of Fisheries and Aquatic Sciences, vol. 47, p. 395-400. http://dx.doi.org/10.1139/f90-041

VAN GOOL, E. and RINGELBERG, J. 1998a. Quantitative effects of fish kairomones and successive light stimuli on downward swimming responses of
Daphnia. Aquatic Ecology, vol. 291, p. 291-296. http://dx.doi.org/10.1023/A:1009917929959

VAN GOOL, E. and RINGELBERG, J. 1998b. Lightinduced migration behaviour of Daphnia modified by food and predator Kairomones. Animal Behaviour, vol. 56, p. 741-747. PMid:9784225. http://dx.doi. org/10.1006/anbe.1998.0821

WILLIAMSON, CE. 1983. Behavioral interactions between a cyclopoid copepod predator and its prey. Journal of Plankton Research, vol. 5, no. 5, p. 701-711. http://dx.doi.org/10.1093/plankt/5.5.701

WISSEL, B. and RAMACHARAN, CW. 2003. Plasticity of vertical distribution of crustacean zooplankton in lakes with varying levels of water colour. Journal of Plankton Research, vol. 25, no. 9, p. 1047-1057. http://dx.doi.org/10.1093/plankt/25.9.1047

WRIGHT, S. 1936. Preliminary report on six new species of Diaptomus from Brazil. Annaes da Academia Brasileira de Sciencias, v. 8, n. 2, p. 79-85.

ZARET, TM. 1980. The effect of prey motion on planktivore choice. In KERFOOT, WC., ed. Evolution and Ecology of zooplankton communities. p. 594-603.

Received: 01 December 2010 Accepted: 02 July 2012 